\title{
Suspected veterinary poisoning cases: A retrospective toxicoepidemiology study (2009-2019) in south-eastern Italy
}

\author{
Daniela Chirizzi*, Raffaella Manca, Simona Summa, Isabella Paciolla, Mariateresa Toce, Antonella Romano and Marilena Muscarella \\ Istituto Zooprofilattico Sperimentale della Puglia e della Basilicata (IZSPB), Via Manfredonia, 20 Foggia Italy
}

\begin{abstract}
The Istituto Zooprofilattico Sperimentale of Puglia and Basilicata (IZSPB) processed toxicoepidemiological data on suspected veterinary intentional poisoning cases (small, farm and wild animals) in South-Eastern Italy. Suspected poisoned animals (SPAs) and supposed poisoning baits (SPBs) were collected between 2009 and 2019 by public health authorities, veterinary practitioners and owners and were analyzed for the presence of rodenticide (non-anticoagulant rodenticides and coumarin derivatives), molluschicide, herbicides, pesticide and other molecules (ethylene glycol and metals). Among SPAs analyzed, small animals were prominent (76.2\%). In totally, $23.7 \%$ animals (408/1719) and $47.3 \%$ baits (224/474) were found positive. Small animals were positive in $26.0 \%$ of cases (341/1310) and the molecule more involved was metaldehyde, a molluschicide. Only 11.4\% (16/123) farm animals were found positive prevalently for rodenticide and pesticide. Though wild ones $18.5 \%$ (53/286) were positive mainly for pesticide. In South-Eastern Italy, there are still limited, and fragmented data published on the topic, although this type of information is crucial in an attempt to reduce this illegal practice.
\end{abstract}

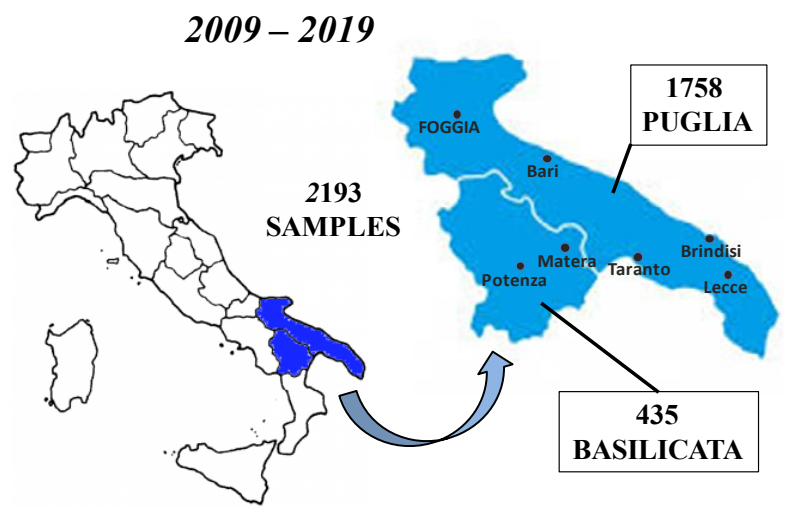

\section{Introduction}

In Italy, preparation, possession and use of poisoned baits are prohibited and actually regulated by Ministerial Ordinance 12 July 2019 [1], which resumes the previously in force regulations (Royal Decree $\mathrm{n}$. 126527 July 1934, Law n. 96827 December 1977, Law n. 15711 February 1992, Ministerial Ordinance 18 June 2009, Ministerial Ordinance 10 February 2012 and Ministerial Ordinance 13 June 2016). Crucial points of the regulatory process were the foundation at Istituto Zooprofilattico Sperimentale of Lazio and Toscana (IZSLT) of: 1) National Institute of Forensic Veterinary Medicine (CeMedForVet) which the purpose of developing and standardizing laboratory techniques and forensic toxicology; 2) Veterinary Poisoning Portal which highlights the primary importance of collection and processing data provided by the national network. Another important target was achieved with the Law n.189/2004 [2], which recognizes as a penal crime the mistreatment and killing of animals.
The poisoning of domestic, farm and wild animals is a frequent event as reported in literature [3-15]. One of the most important triggers of animal poisoning has been reported in toxic baits prepared with different substances easily available in many formulations and buyable without any particular restriction $[3,7,16]$. However, it should not be underestimated accidental ingestion of drug improperly used and stored $[17,18]$.

${ }^{*}$ Correspondence to: Daniela Chirizzi, Istituto Zooprofilattico Sperimentale della Puglia e della Basilicata (IZPB), Via Manfredonia, 20 Foggia Italy, E-mail: daniela.chirizzi@izspb.it

Key words: toxicoepidemiology, small animals, farm animal, wild animal, poisoning

Received: August 30, 2020; Accepted: September 14, 2020; Published: September 19, 2020 
As required by law, every time a new case occurs, owners may report animal poisoning cases (bait samples and suspected poisoned animal tissues) to veterinary institutions and consequently to the Instituti Zooprofilattici Sperimentali (IIZZSS) competent for the territory that are official control laboratories for diagnostic and toxicological analysis. Suspected cases of poisoning may be caused by wide range of toxicants. In this report, we analyze the most common molecules involved in intentional poisoning as rodenticides non-anticoagulant and rodenticides coumarin derivatives, herbicides, molluschicide, pesticide.

Rodenticides are toxic to many species of birds and mammals including pets, farm animals, and wildlife species. Their ubiquitous use to control unwanted rodent populations has historically proved a problem for a wide variety of animals. This occurs either because pets and wildlife are attracted to the bait (which contains the toxin in a highly palatable form) or may prey upon and ingest the alreadypoisoned rodents [19-21]. Rodent poisons can be split into two general categories, anticoagulants and non-anticoagulants. Anticoagulant rodenticides work by interfering with the activation of Vitamin $\mathrm{K}$, a critical component in the production of blood clotting factors in the liver. Non-anticoagulant rodenticides vary in their mechanism of action and include bromethalin, strychnine, cholecalciferol and zinc phosphide.

Pesticides are extensively utilized for control of crop pests in agricultural and forestry sectors, and can be used at home and at work to eradicate household pests. Most poisonings by pesticides occur because of misuse or accidental exposure and is of particular importance for affecting domestic animals and livestock [22-27]. Pesticides commonly used are organophosphates (OPs), carbamates, pyrethrins, and pyrethroids, as well as some newer insecticides. OPs and carbamates, used to control insect and nematode infestation, competitively inhibit acetylcholinesterase (AChE) [28,29].

Molluschicides for the control of slugs and snails and metaldehyde is a common ingredient are worldwide used. Metaldehyde-based pellets are commonly formulated with milling and pasta wheat in order to entice target species and those same palatability characteristics appear to render them attractive to animals. Metaldehyde intoxication in dogs occurs frequently, and has been reported in many other species, including cats, cattle, sheep, horses and birds [30-37].

Herbicide (diquat and paraquat) have been sporadically involved in poisoning animals. One of the most widely used herbicides is glyphosate which nevertheless has minimal poisoning power in animals [38] although surfactants used in the liquid formulation of glyphosate, such as polyoxyethylene amine, may be toxic [39-41].

Paraquat is a contact-action herbicide, used to control a broad range of unwanted plants. Other herbicides and fungicides are seldom involved in poisoning in companion animals, except for chlorates $[42,43]$.

In this paper we present and discuss the data on suspected poisoning cases, collected in the period 2009-2019 at the Istituto Zooprofilattico Sperimentale of Puglia and Basilicata, after the approbation of Ministerial Ordinance (18December 2008)on the prohibition of using and possessing poisoned bites [44]. With this law, IIZZSS are designated as a reference laboratory and IZSPB was the public veterinary health institute competent for the regions of South-Eastern Italy for chemicaltoxicological analysis.

\section{Material and methods}

Data for this retrospective study were taken from analysis collected in Puglia and Basilicata ranging from January 2009 to December 2019, send for necropsy and/or toxicological examination. Chemistry Department of Istituto Zooprofilattico Sperimentale of Puglia and Basilicata, in Foggia, performed the analysis.

Owners or finders furnished all the information about the sample, animal species, age, gender, circumstances of death, and place of discovery. Chemical analyses were performed on 474 suspected bait samples and organs/biological fluid ones (i.e. liver, stomach, gastric content) of 1310 small animals (907 dogs and 403 cats), 123 farm animal and 286 wild animals. A total of 1719 organs from animals (small animal, farm animal and wild animal) and 474 pieces of bait were analysed for the presence of rodenticides non-anticoagulant (Arseniuri/fosfuri) and rodenticides coumarin derivatives (coumafouryl, warfarin, coumachlor, coumatetralyl, bromadiolone, flocoumafen, difenacoum, brodifacoum); herbicides (diquat, paraquat), molluschicide (metaldehyde), pesticide (organophosphorus pesticide and carbamate) and other molecules (i.e. ethylene glycol, metals).

The determination of rodenticides non-anticoagulant (Arseniuri/ fosfuri) by qualitative colorimetric assay (presence, absence) with $20 \%$ sulphuric acid and 10\% silver nitratewere performed. Pesticides (phosphoric ester) were individuated by Kit Agri-Screen ticket (Neogen Corporation), a biochemical assay capable of detecting the main types of organophosphorus pesticides, thiophosphates and carbamates. Herbicides (diquat e paraquat) and molluschicide analysis were performed by qualitative colorimetric assay (presence, absence). Rodenticides coumarin derivatives determination was performed by HPLC/FLD and expressed in $\mathrm{mg} / \mathrm{kg}$ (not revealed $\mathrm{c}<=2.5 \mathrm{mg} / \mathrm{kg}$ ).

\section{Results and discussion}

\section{Number and classification of samples}

All samples collected for the report (2193) including baits (474), cadavers (1378), organs (324), and other biological materials (17) were analyzed, and $28.8 \%$ (632) resulted positive to chemical-toxicological studies. The distribution of the toxicological classes examined among the positive samples were illustrated in Figure 1. The positive samples were represented as follows: molluschicide $(44.8 \%)$, pesticides $(28.8 \%)$, rodenticides $(25.3 \%)$ and other molecules $(1.1 \%)$. Confirmed positive cases were constituted by 408 animals and 224 baits.

As shown in Figure 2, data recorded on suspected poisoned animals (SPAs) were predominantly related to small animals (76.3\%) and to some extent to wild animals (16.6\%). Few data were registered involving farm animal (7.1\%).

The analyses on 1719 SPAs showed that 408 (23.7\%) were positive to chemical-toxicological study. Metaldehyde (molluschicide) was the primary cause of poisoning (42.4\%); followed by pesticide $(29.7 \%)$; rodenticide $(26.5 \%)$ and other molecules (ethylene glycol, metals $1.2 \%$ ) (Figure $3 \mathrm{~A}$ ). Suspected poisoning baits (474) were positive in $47.3 \%$ of cases (224) and collected data evidenced that metaldehyde (molluschicide) was the primary molecules involved (49.3\%), followed by pesticide (26.9\%), rodenticide (23.3\%) and other molecules (ethylene glycol, metals $0.9 \%$ ) (Figure 3B).

The group of SPAs was constituted mainly by small animals (76.2\%, 1310 animals), which were positive in $26.0 \%$ of total case (341). The group of pets was constituted for $79.2 \%$ by dogs and $20.8 \%$ by cats. As reported in Figure 4A, dogs resulted positive to chemical- 


\section{CONFIRMEDCASES}

TOTAL CASES (2193)

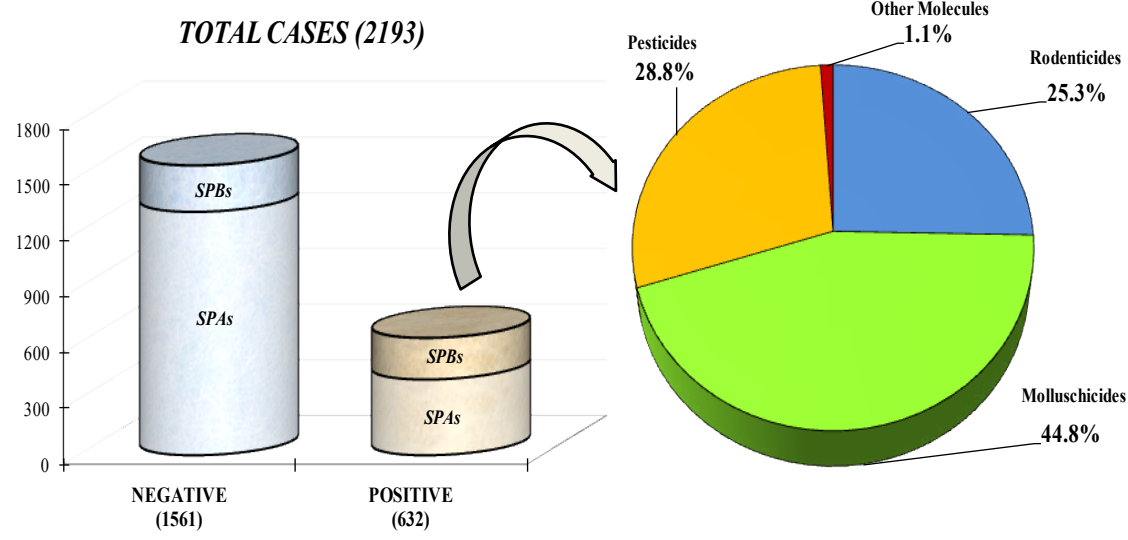

Figure 1. Graphic representation of chemical-toxicological results of 2193 suspected total cases collected in Puglia and Basilicata (2009-2019). In Zoom the distribution of the toxicological classes examined among the positive samples. (SPBs: supposed poisoning baits; SPAs: suspected poisoned animals)

SUSPECTED POISONED ANIMALS (1719)

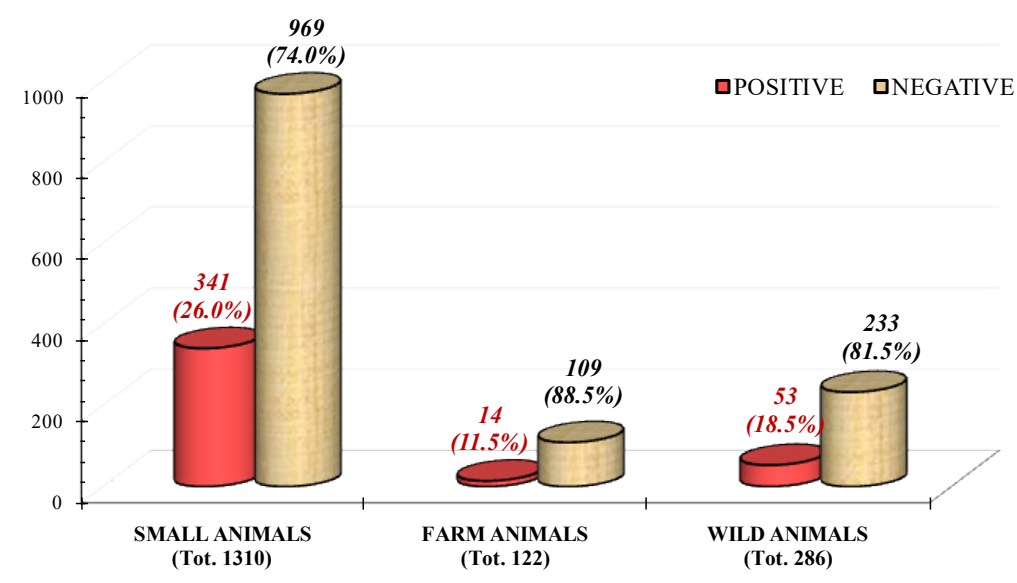

Figure 2. Suspected animals poisoning distribution (positive and negative) among small animals, farm animals and wild animals collected in Puglia and Basilicata (2009-2019)

toxicological studies in $29.8 \%$ of cases, while cats in $18.2 \%$. In general, the dog resulted to be the species more involved in animal poisoning, in agreement with other reports $[39,45,46]$. In this species, molluschicide metaldehyde was the most commonly found molecule with $53.0 \%$ of confirmed cases, followed pesticide (23.7\%); rodenticide $(23.0 \%)$ and other molecules (0.4\%) (Figure 4B).

Even among cats, the highest number of positives (39.4\%) are relative to molluschicide metaldehyde poisoning, followed by rodenticide (38.0\%) and pesticide (22.5\%) (Figure 4C).

Wild animals (wolf, badger, fox, rabbit and birds) constituted the second class of representative animals (286 cases). Thoughthis last group, the $18.5 \%$ of samples resulted positive to analysis and pesticide (71.7\%) constituted the primary group of toxicants, followed by rodenticide (24.5\%) and molluschicides (3.8\%).

The last group considered (farm animals) was composed by horses, sheep and goats, cows (123 cases). Only $10.7 \%$ of farm animals were found positive and, when found, molecules more involved were rodenticide followed by pesticide and other molecules.

Moreover, in baits, metaldehyde was confirmed as the most commonly used substance for poisoning in $49.1 \%$ of cases, followed by rodenticide $(26.8 \%)$, pesticides $(23.2 \%)$, and others molecules (0.9\%).

In detail, the collected data for Puglia and Basilicata from 2009 to 2019 have been reported below in Table 1. While in Table 2, we illustrated distribution of toxicological groups between small, farm and wild animals.

\section{Consideration of poisoning groups}

Molluschicides: Molluschicides were the toxicological class more involved in poisoning animals cases and metaldehyde was the molecule more found according to literature $[45,47,48]$. Metaldehyde was found in 143 dogs, 28 cats, 1 fox and 1 pigeon.

The high lethality index of this molluschicide, the rapid onset of clinical signs and the absence of a specific antidote makes this molecule very dangerous. Add to this its wide use in the domestic environment, its palatability and ease of supply. This probably justifies why most of the animals in which this molecule was found were small animals, mainly in dogs, less selective in food supply.

In baits, molluschicide metaldehyde was the molecule more found (49.1\% of positive baits). Often the presence of metaldehyde was detectable in both SPAs and SPBs for the same clinical case. 


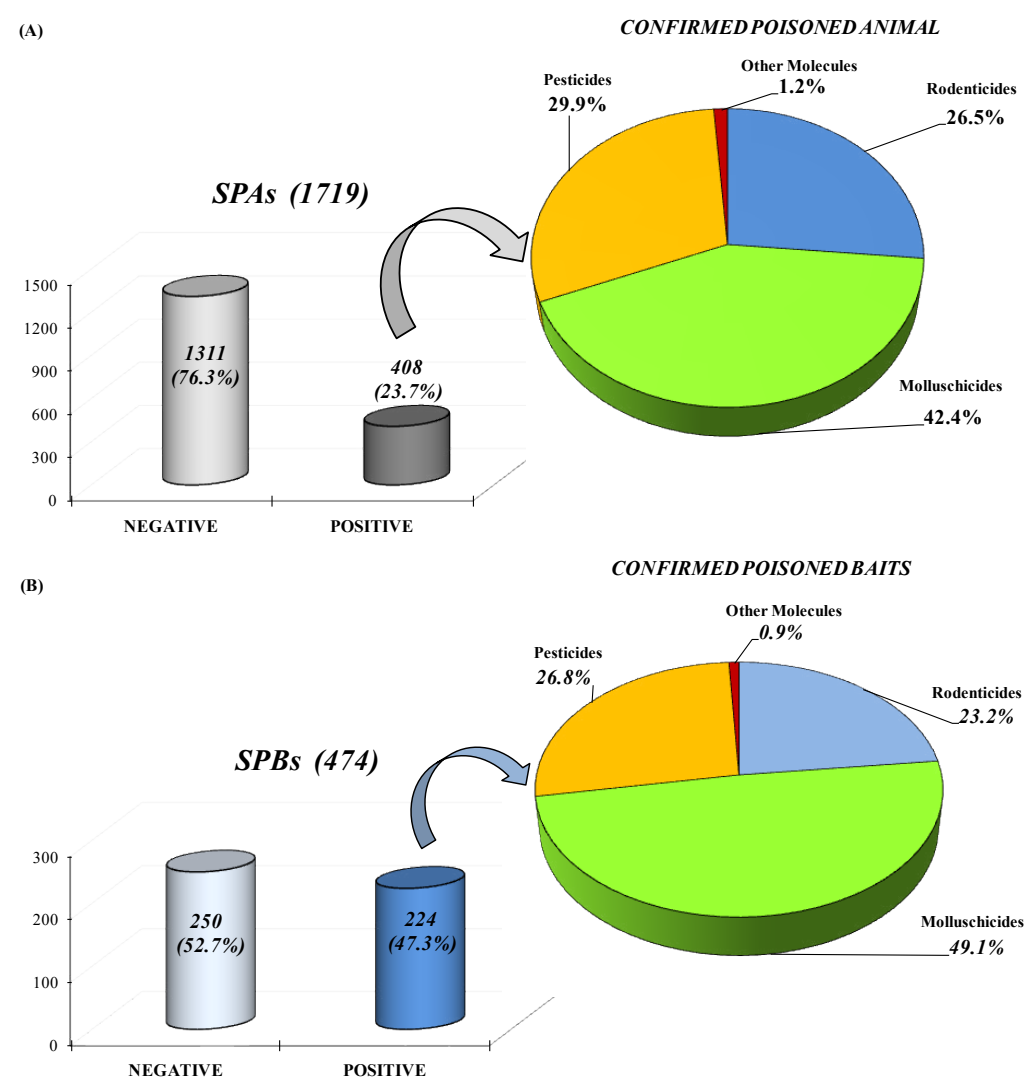

Figure 3. Graphic representation of toxicological class evidenced in toxicological studies among total suspected poisoned animals (A) and supposed poisoning baits (B) for Puglia and Basilicata (2009-2019)

(A)

SMALL ANIMALS (1310)

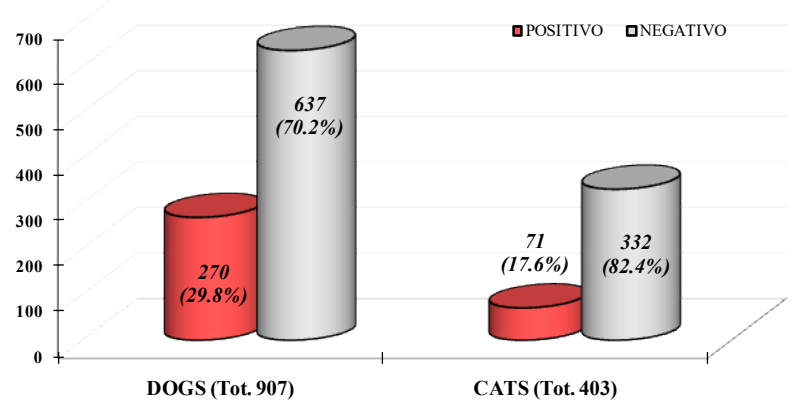

(B)

(C)

POSITIVE CATS
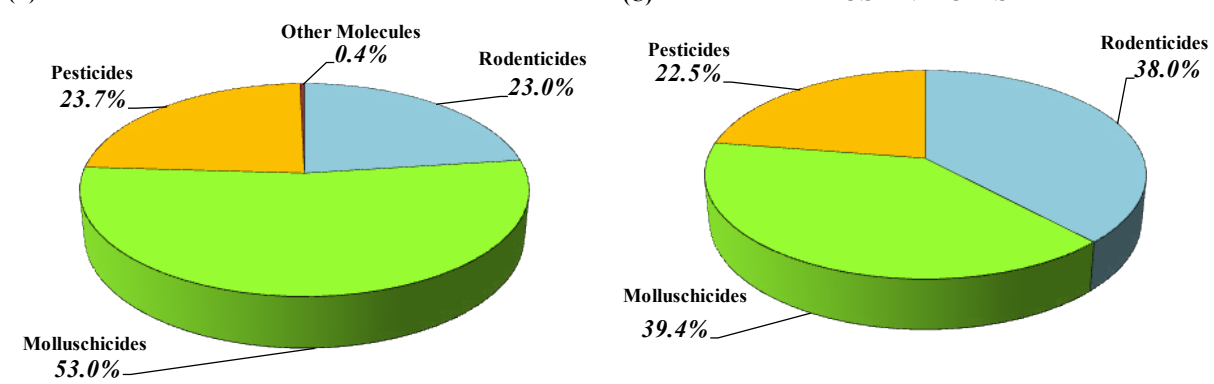

Figure 4. Graphic representation of chemical-toxicological results (A) among suspected poisoned small animals. Explanation of molecules involved and distinction between confirmed poisoned dogs (B) and cats (C) for Puglia and Basilicata (2009-2019) 
Table 1. Poisonous substances detected in suspected poisoned animals (SPAs) and supposed poisoning baits (SPBs) in Puglia and Basilicata between January 2009 and December 2019.

\begin{tabular}{|c|c|c|c|c|c|c|c|}
\hline \multirow[b]{3}{*}{ Rodenticides } & \multirow[b]{2}{*}{ Coumarin Derivates } & \multicolumn{2}{|c|}{$\begin{array}{c}\text { Total Cases } \\
2193\end{array}$} & \multicolumn{2}{|c|}{$\begin{array}{l}\text { SAPs } \\
1719\end{array}$} & \multicolumn{2}{|c|}{$\begin{array}{c}\text { SPBs } \\
474\end{array}$} \\
\hline & & 111 & $5.1 \%$ & 79 & $4.6 \%$ & 32 & $6.8 \%$ \\
\hline & $\begin{array}{l}\text { Non-Anticoagulant } \\
\text { Rodenticides }\end{array}$ & 49 & $2.2 \%$ & 29 & $1.7 \%$ & 20 & $4.2 \%$ \\
\hline \multicolumn{2}{|c|}{ Herbicides } & 0 & $0.0 \%$ & 0 & $0.0 \%$ & 0 & $0.0 \%$ \\
\hline \multicolumn{2}{|c|}{ Molluscicides } & 283 & $12.9 \%$ & 173 & $10.1 \%$ & 110 & $23.2 \%$ \\
\hline \multicolumn{2}{|c|}{ Pesticides } & 182 & $8.3 \%$ & 122 & $7.1 \%$ & 60 & $12.7 \%$ \\
\hline \multicolumn{2}{|c|}{ Other Molecules } & 7 & $0.3 \%$ & 5 & $0.3 \%$ & 2 & $0.4 \%$ \\
\hline \multicolumn{2}{|c|}{ Negative } & 1561 & $71.18 \%$ & 1311 & $76.3 \%$ & 250 & $52.7 \%$ \\
\hline
\end{tabular}

Table 2. Poisonous substances detected in relation to animal class in suspected voluntary poisoning in Puglia and Basilicata between January 2009 and December 2019.

\begin{tabular}{|c|c|c|c|c|c|c|c|}
\hline \multirow[b]{3}{*}{ Rodenticides } & \multirow[b]{2}{*}{ Coumarin Derivates } & \multicolumn{2}{|c|}{$\begin{array}{c}\text { Small } \\
1310\end{array}$} & \multicolumn{2}{|c|}{$\begin{array}{c}\text { Farm } \\
123\end{array}$} & \multicolumn{2}{|c|}{$\begin{array}{l}\text { Wilds } \\
286\end{array}$} \\
\hline & & 66 & $5.0 \%$ & 2 & $1.6 \%$ & 11 & $23 \%$ \\
\hline & $\begin{array}{l}\text { Non-Anticoagulant } \\
\text { Rodenticides }\end{array}$ & 23 & $1.8 \%$ & 4 & $3.3 \%$ & 2 & $0.4 \%$ \\
\hline \multicolumn{2}{|c|}{ Herbicides } & 0 & $0.0 \%$ & 0 & $0.0 \%$ & 0 & $0.0 \%$ \\
\hline \multicolumn{2}{|c|}{ Molluscicides } & 171 & $13.1 \%$ & 0 & $0.0 \%$ & 2 & $0.4 \%$ \\
\hline \multicolumn{2}{|c|}{ Pesticides } & 80 & $6.1 \%$ & 4 & $3.3 \%$ & 38 & $8.0 \%$ \\
\hline \multicolumn{2}{|c|}{ Other Molecules } & 1 & $0.1 \%$ & 4 & $3.3 \%$ & 0 & $0.0 \%$ \\
\hline \multicolumn{2}{|c|}{ Negative } & 969 & $73.97 \%$ & 109 & $88.6 \%$ & 233 & $49.2 \%$ \\
\hline
\end{tabular}

Rodenticides: Rodenticides, compounds palatable, largely used in domestic and rural environment and easily available, are the second most represented class of molecules.

Exposure to rodenticides accounted for $7.3 \%$ of the total samples (Table 1) and the group more evidenced were coumarin (5.1\%) (Figure 1). The coumarin molecules more involved were coumachlor and bromadiolone, and the species more involved in poisoning were dog and cat in according to previous report of IZSPB [49]. Moreover, we evidenced presence of cumarinin molecules in one horse and one rooster and in the group of wild animals in five birds, six rabbit and one fox, probably as consequence of environmental deratization treatments. Zinc phosphide, an old but still largely employed non-anticoagulant rodenticide, and arseniuri were reported as causing toxicity in fourteen dogs, three sheeps, two cats and two wolves. Regarding suspected baits, $11.0 \%$ turned to be positive for rodenticides (6.7\%coumarin molecules and $4.3 \%$ non-anticoagulant rodenticide). Samples containing more than one compound were found and were characterized by the presence of coumachlor- bromadiolone; coumatetralyl-difenacoum and coumafouryl-difenacoum.

Herbicides: No cases of herbicides poisoning were found in this study. This result according with Berny et al. [6] who reported that intoxications with herbicides were frequently suspected but rarely confirmed in pet toxicities. Only one case of sheep poisoned by copper sulfate, a poorly toxic product commonly used as a fertilizer and fungicide, was found.

Pesticides: Anticholinesterase insecticides (carbamates and organophosphates) were the pesticide commonly found and dogs were the species more involved ( $90.0 \%$ of total cases). The reported data highlight the presence of pesticides in all animals groups, representing the first cause of poisoning in wild animals. Often carbamates and organophosphates were found associated in the same samples, mainly in baits.

\section{Conclusion}

This study conducted in South East Italy (Puglia and Basilicata) in 2009-2019 shows that the poisoning of animals is a widespread practice and still represents a significant cause of death in veterinary medicine. It is more likely that many of the recorded cases were related to an accidental ingestion of toxic substances left unattended or used without thinking about the consequences on animals. Different was for baits, whose presence and finding presupposes intentional poisoning. In fact, in this case the possibility of tracing the presence of a toxic substance was clearly higher, with percentages reaching $47.1 \%$ in the presence of the single bait and $79.0 \%$ when the bait was associated with the presence of a poisoned animal. It must also be considered the possibility of false negatives due to the failure to identify the molecule involved, considering the vastness of toxic substances available and the continuous development of new chemical compounds. In conclusion, this retrospective study, despite not absolutely establish if each poisoned animal was due to criminal intents, shows that the abuse or misuse of toxic substances is very common in South-East Italy and still far from being eradicated. The hope is that the activation of the National Poisoning Portal will make more efficient and extensive the detection of this illegal practice, too often unpunished even if considered a criminal offense by Italian Law n. 189/2004 on animal abuse.

\section{Conflict of interest statement}

None of the authors of this paper has a financial or personal relationship with other people or organizations that could inappropriately influence or bias the content of the paper.

\section{Acknowledgement}

The authors would like to thank Dr. Giuseppina Ciccarese, Dr. Matteo Beverelli, Dr. CosimoMontagna, Dr. Meri Gazzaneo, Dr. Roberta Catanzariti, Dr. Lucia Palazzo and Dr. Gianfranco Santagada for providing their data.

\section{References}

1. Ministerial Ordinance - 12 July 2019, Norme sul divieto di utilizzo e di detenzione di esche o di bocconi avvelenati. Italian Official Journal n. 196 of 22 August 2019.

2. Law n. 18920 July 2004. Disposizioni concernenti il divieto di maltrattamento degli animali, nonché di impiego degli stessi in combattimenti clandestini o competizioni non autorizzate. Italian Official Journal n. 178 of 31 July 2004. 
3. Amorena M, Caloni F, Mengozzi G (2004) Epidemiology of intoxications in Italy. Vet Res Commun 28: 89. [Crossref]

4. Wobeser G, Bollinger T, Leighton FA, Blakley B, Mineau P (2004) Secondary poisoning of eagles following intentional poisoning of coyotes with anticholinesterase pesticides in western Canada. J Wildl Dis 40: 163-172. [Crossref]

5. Guitart R, Croubels S, Caloni F, Sachana M, Davanzo F, et al. (2010a) Animal poisoning in Europe. Part 1: Farm livestock and poultry. Vet $J$ 183: 249-254. [Crossref]

6. Berny P, Caloni F, Croubels S, Sachana M, Vandenbroucke V, et al. (2010) Animal poisoning in Europe. Part 2: companion animals. Vet $J$ 183: 255-259. [Crossref]

7. Guitart R, Sachana M, Caloni F, Croubels S, Vandenbroucke V, et al. (2010b) Anima poisoning in Europe. Part 3: Wildlife. Vet $J$ 183, 260-265. [Crossref]

8. Giorgi M, Mengozzi G (2011) Malicious animal intoxications: poisoned baits. Veterinarni Medicina 56: 173-179.

9. Bille L, Toson M, Mulatti P, Dalla Pozza M, Capolongo F, et al. (2016) Epidemiology of animal poisoning: An overview on the features and spatio-temporal distribution of the phenomenon in the north-eastern Italian regions. Forensic Sci Int 266: 440-448. [Crossref]

10. Chiari M, Cortinovis C, Vitale N, Zanoni M, Faggionato E, et al. (2017) Pesticide incidence in poisoned baits: a 10-year report. Sci Total Environ 601:285-292. [Crossref]

11. De Roma A, Miletti G, D’Alessio N, Rossini C, Vangone L, et al. (2017) Metaldehyde poisoning of companion animals: a three-year retrospective study. $J$ Vet Res 61: 307311. [Crossref]

12. Asawari R, Atmaram P, Bhagwan K, Priti D, Kavya S, et al. (2017) Toxicological pattern of poisoning in urban hospitals of western India. Journal of Young Pharmacists 9: 315 .

13. Gwaltney-Brant SM (2018) Epidemiology of animal poisonings in the United States. Veterinary Toxicology, pp. 37-44.

14. Di Blasio A, Bertolini S, Gili M, Avolio R, Leogrande M, et al. (2020) Local context and environment as risk factors for acute poisoning in animals in northwest Italy. $S c$ Total Environ 709: 136016. [Crossref]

15. Bertero A, Fossati P, Caloni F (2020) Indoor poisoning of companion animals by chemicals. Sci Total Environ.

16. Giorgi M, Meucci V, Loni R, Soldani G, Mengozzi G (2002) Veterinary medicine intoxications cases reported by the Laboratory of Toxicology of Veterinary Medicine Faculty of Pisa in 1999-2001 years. O\&DV Obiettivi e Documenti Veterinari (Italy).

17. Fitzgerald KT, Bronstein AC, Flood AA (2006) "Over-the-counter" drug toxicities in companion animals. Clin Tech Small Anim Pract 21: 215-226. [Crossref]

18. Siroka Z, Svobodova Z (2013) The toxicity and adverse effects of selected drugs in animals-overview. Pol J Vet Sci 16. [Crossref]

19. Merola V (2002) Anticoagulant rodenticides: deadly for pests, dangerous for pets. Veterinary Medicine 97: 716-727.

20. Berny P, Velardo J, Pulce C, D'amico A, Kammerer M, et al. (2010) Prevalence of anticoagulant rodenticide poisoning in humans and animals in France and substances involved. Clin Toxicol 48: 935-941. [Crossref]

21. Valchev I, Binev R, Yordanova V, Nikolov Y (2008) Anticoagulant rodenticide intoxication in animals-a review. Turkish Journal of Veterinary and Animal Sciences 32: $237-243$.

22. Xavier FG, Kogika MM (2002) Common causes of poisoning in dogs and cats in a Brazilian veterinary teaching hospital from 1998 to 2000. Vet Hum Toxicol 44: 115116. [Crossref]

23. Wang Y, Kruzik P, Helsberg A, Helsberg I, Rausch WD (2007) Pesticide poisoning in domestic animals and livestock in Austria: a 6 years retrospective study. Forensic Sci Int 169: 157-160. [Crossref]

24. Novotný L, Misík J, Honzlová A, Ondráček P, Kuča K, et al. (2011) Incidental poisoning of animals by carbamates in the Czech Republic. Journal of Applied Biomedicine 9 : 157-161.

25. Ruiz-Suárez N, Boada LD, Henríquez-Hernández LA, González-Moreo F, SuárezPérez A, et al. (2015) Continued implication of the banned pesticides carbofuran and aldicarb in the poisoning of domestic and wild animals of the Canary Islands (Spain). Sci Total Environ 505: 1093-1099.

26. Lahmar R, Berny P, Mahjoub T, Youssef SB (2019) Animal pesticide poisoning in Tunisia. Frontiers in Veterinary Science.
27. Bertero A, Chiari M, Vitale N, Zanoni M, Faggionato E, et al. (2020) Types of pesticides involved in domestic and wild animal poisoning in Italy. Sci Total Environ 707: 136129. [Crossref]

28. Wismer T, Means C (2018) Toxicology of newer insecticides in small animals Veterinary Clinics: Small Animal Practice 48: 1013-1026.

29. Fikes JD (1990) Organophosphorus and carbamate insecticides. Veterinary Clinics of North America: Small Animal Practice 20: 353-367.

30. Udall ND (1973) The toxicity of the molluscicidesmetaldehyde and methiocarb to dogs. Veterinary Record 93: 420-422.

31. Campbell A (2008) Metaldehyde poisoning of dogs. Veterinary Record 163: 343-343.

32. Van Pelt H, Mostin M (2010) March. Effect of risk-reducing actions on metaldehyde intoxications by dogs. Clinical Toxicology 48: 315 .

33. Dolder LK (2003) Metaldehydetoxicosis. Veterinary Medicine 98: 213-215.

34. Yas-Natan E, Segev G, Aroch I (2007) Clinical, neurological and clinicopathological signs, treatment and outcome of metaldehyde intoxication in 18 dogs. $J$ Small Anim Pract 48: 438-443. [Crossref]

35. Studdert VP (1985a) Incidence of poisonings in dogs and cats in Melbourne. Aust Vet J 62: 133-135. [Crossref]

36. Studdert VP (1985b) Epidemiological features of snail and slug bait poisoning in dogs and cats. Aust Vet $J$ 62: 269-272. [Crossref]

37. Firth AM (1992) Part 2: treatment of snail bait toxicity in dogs: retrospective study of 56 cases. Journal of Veterinary Emergency and Critical Care 2: 31-36.

38. Kammerer M (1995) Intoxication par les herbicides à base de glyphosate. Rec MédVét 171: 3 .

39. Burgat V, Keck G, Guerre P, Bigorre V, Pineau X (1998) Glyphosate toxicosis in domestic animals: a survey from the data of the Centre National d'InformationsToxicol ogiquesVeterinaires (CNITV). Vet Hum Toxicol 40: 363-367. [Crossref]

40. Antoniou V, Zantopoulos N, Tsitsamis S (1998) Poisoning with substances in dogs and cats: a report of 129 cases. Anima 6: 6 .

41. Motas-Guzmán M, Marla-Mojica P, Romero D, Martínez-López E, García-Fernández AJ (2003) Intentional poisoning of animals in southeastern Spain: a review of the veterinary toxicology service from Murcia, Spain. Vet Hum Toxicol 45: 47. [Crossref]

42. Barbier N (2005) Biland'activité du Centre National d'InformationsToxicologiquesVétérinaires pour l'année 2003. Thèse de doctoratvétérinaire, Lyon, $220 \mathrm{pp}$.

43. Williams AL, Watson RE, DeSesso JM (2012) Developmental and reproductive outcomes in humans and animals after glyphosate exposure: a critical analysis. $J$ Toxicol Environ Health B Crit Rev 15: 39-96. [Crossref]

44. Ministerial Ordinance 18 December 2008. Normesuldivieto di utilizzo e di detenzione di esche o di bocconiavvelenati. Italian Official Journal n. 13 of 17 January 2009.

45. Albo AG, Nebbia C (2004) Incidence of poisonings in domestic carnivores in Italy. Vet Res Commun 28: 83. [Crossref]

46. Bates NS, Sutton NM, Campbell A (2012) Suspected metaldehyde slug bait poisoning in dogs: a retrospective analysis of cases reported to the Veterinary Poisons Information Service. Veterinary Record 171: 324-324.

47. Nolte I (2012) Toxicity of metaldehyde in the dog and cat. PraktischerTierarzt 93 (10) 886-893.

48. Teichmann Knorrn S, Doerfelt S, Doerfelt R (2020) Retrospective evaluation of the use of hemodialysis in dogs with suspected metaldehyde poisoning (2012-2017) 11 cases. Journal of Veterinary Emergency and Critical Care 30: 194-201.

49. Muscarella M, Armentano A, Iammarino M, Palermo C, Amorena M (2016) Anticoagulant rodenticide poisoning in animals of Apulia and Basilicata, Italy. Veterinariaitaliana 52: 153-159.

Copyright: (C2020 Chirizzi D. This is an open-access article distributed under the terms of the Creative Commons Attribution License, which permits unrestricted use, distribution, and reproduction in any medium, provided the original author and source are credited. 